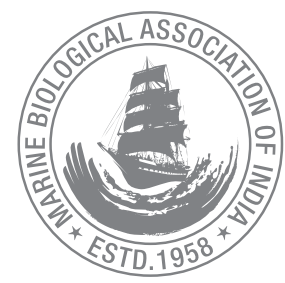

\title{
First report of the crocodile shark Pseudocarcharias kamoharai (Matsubara,1936)from Chennai, southeast coast of India
}

\author{
Shoba Joe Kizhakudan* and S. Rajapackiam \\ Madras Research Centre of Central Marine Fisheries Research Institute, Chennai -600028, Tamil Nadu, India. \\ ${ }^{*}$ Correspondence e-mail: shobajoe@rediffmail.com
}

Received: 27 Jul 2012, Accepted: 30 Mar 2013, Published: 30 Apr 2013

\begin{abstract}
This paper reports the occurrence of the crocodile shark Pseudocarcharias kamoharai in the waters off Chennai in the south-east coast of India and is a new locality record for the species, confirming its distribution in the Bay of Bengal. P. kamoharai is the only representative of the family Pseudocarchariidae and is the smallest known living mackerel shark (Order: Lamniformes). A single adult male specimen measuring $91 \mathrm{~cm}$ in total length and weighing $2.2 \mathrm{~kg}$ weight was collected from the landings by a deep sea trawler at Chennai Fisheries Harbour, caught in hook and line operations for yellow-fin tuna in the waters off the Chennai - Puducherry coast, at a depth of $300 \mathrm{~m}$. Reported to occur as by-catch in Japanese yellow fin tuna long line fishery and Australian swordfish fishery, both in the Indian Ocean, it has been classified as "Near Threatened" by IUCN.
\end{abstract}

Keywords: Bay of Bengal, Chennai, crocodile shark, Pseudocarcharias kamoharai, South-east India.

\section{Introduction}

The crocodile shark Pseudocarcharias kamoharai (Matsubara, 1936 ) is the only representative of the family Pseudocarchariidae and is the smallest known living mackerel shark (Order: Lamniformes). Known to be circumtropical in distribution, with its range extending from Eastern Atlantic Ocean to the
Pacific Ocean, its occurrence in the Indian Ocean has been reported from the Mozambique Channel, southwest of southern Madagascar while its distribution in the Bay of Bengal has been reported as doubtful (D' Aubrey 1964; Long and Seigel, 1997).

There is no known fishery for the species and it does not find much commercial significance on account of its rare abundance in well-exploited fishing grounds, small-size and low quality of meat. No data is available on the population status of this species and its abundance has been reported only in the Mozambique Channel in the Western Indian Ocean in the 1960s (Compagno, 2001). The present report records the occurrence of $P$. kamoharai in the waters off Chennai in the south-east coast of India and is a new locality record for the species, confirming its distribution in the Bay of Bengal.

\section{Material and methods}

On February 10, 2011, a single specimen of the crocodile shark $P$. kamoharai was collected from the landings by a deep sea trawler at Chennai Fisheries Harbour. The specimen had been caught by hook and line operated for yellow-fin tuna in the waters off the Chennai - Puducherry coast, at a depth of $300 \mathrm{~m}$. The specimen was identified and photographed and morphometric measurements were recorded. The liver was 
measured and weighed separately. The specimen has been deposited at the National Biodiversity Referral Museum at CMFRI, Kochi (Accession No. GA.6.1.2.1.).

\section{Results and discussion}

\section{Pseudocarcharias kamoharai (Matsubara, 1936) (Fig. 1) \\ Order : Lamniformes \\ Family : Pseudocarchariidae}

Material examined: male (adult), $91 \mathrm{~cm} \mathrm{TL}, 2.2 \mathrm{~kg}$ whole body weight

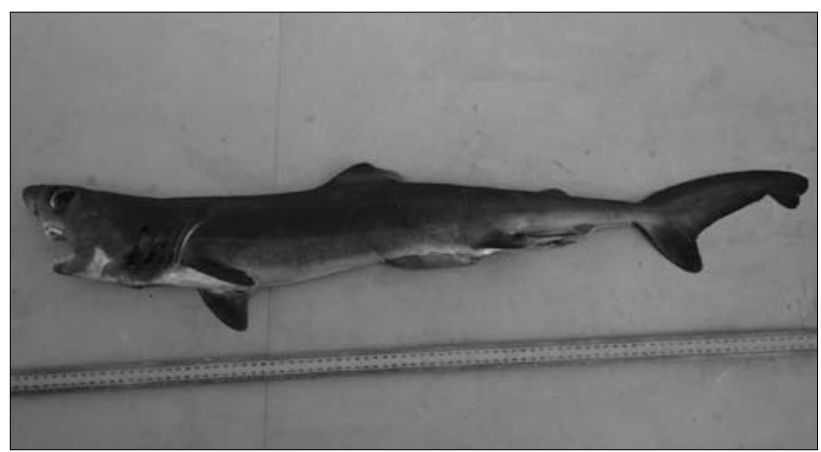

Fig. 1. Crocodile shark Pseudocarcharias kamoharai landed at Chennai



Fig. 2 The head of $P$. kamoharai showing the large eye and awl-like teeth

Diagnosis: A slender-bodied shark with a cylindrical trunk. Head short with moderately long bluntly pointed snout. Eyes large, nictitating eyelids absent. Five pairs of gill slits placed before pectoral fins, all gill slits highly elongate, extending onto dorsal surface of head. Gill rakers absent on internal gill slits. Large mouth placed ventrally on head and bearing large awl-like narrow teeth (Fig. 2); first dorsal fin small, low and angular, placed almost midway between snout and caudal tip; nonpivotable second dorsal fin placed far back near caudal peduncle, smaller than first dorsal but larger than anal fin; anal fin pivotable; pectoral fins small and broad; pelvic fins smaller than first dorsal fin and pectoral fins; caudal fin asymmetrical, not lunate, with moderately long upper lobe and short but strong lower lobe. Caudal peduncle slightly depressed; precaudal pits present; lateral keels on caudal peduncle low. SL $77.5 \%$ of TL; HL $18.1 \%$ of TL; eye diameter $20 \%$ of $\mathrm{HL}$; second dorsal fin height only $48 \%$ of first dorsal fin height. Detailed morphometric measurements are given in Table 1.

The large liver is known to be rich in squalene and is of potential value. The liver in the specimen described here was very oily in touch and gave off a pungent odour. It measured $42 \mathrm{~cm}$ in length $(60 \%$ in the $\mathrm{SL}$ ) and weighed $0.5 \mathrm{~kg}$, accounting for $22.7 \%$ of the total body weight of the shark and occupying almost the entire body cavity (Fig. 3).

Colour: Dark greyish-brown dorsally, fading towards the ventral portion. Fins with dark margins lined thinly with

Table 1. Morphometric details of the crocodile shark Pseudocarcharias kamoharai (male) landed at Chennai

\begin{tabular}{|c|c|}
\hline Dimensions & Measurements $(\mathrm{mm})$ \\
\hline Total length & 910 \\
\hline Standard length & 705 \\
\hline Distance from snout to origin of first dorsal fin & 350 \\
\hline Distance from snout to origin of second dorsal fin & 585 \\
\hline Distance from snout to origin of pectoral fin & 210 \\
\hline Distance from snout to origin of pelvic fin & 510 \\
\hline Distance from snout to origin of ventral fin & 560 \\
\hline Distance from snout to first gill opening & 165 \\
\hline Distance from snout to second gill opening & 180 \\
\hline Distance from snout to third gill opening & 193 \\
\hline Distance from snout to fourth gill opening & 206 \\
\hline Distance from snout to fifth gill opening & 216 \\
\hline Base of first dorsal & 65 \\
\hline Height of first dorsal & 58 \\
\hline Base of second dorsal & 30 \\
\hline Height of second dorsal & 28 \\
\hline Base of pectoral fin & 40 \\
\hline Height of pectoral fin & 32 \\
\hline Base of pelvic fin & 45 \\
\hline Height of pelvic fin & 45 \\
\hline Base of ventral fin & 15 \\
\hline Height of ventral fin & 24 \\
\hline Distance from snout to eye & 65 \\
\hline Eye diameter & 33 \\
\hline Distance from snout to mouth & 45 \\
\hline Distance from snout to nostril & 70 \\
\hline Internaral distance & 28 \\
\hline Length of upper jaw & 140 \\
\hline Length of lower jaw & 105 \\
\hline Length of claspers & 80 \\
\hline Length of gonad & 85 \\
\hline Length of liver & 420 \\
\hline
\end{tabular}






Fig. 3. A view of the shark showing the large liver inside the body cavity

whitish edge. A large whitish blotch present between corner of jaw and first gill slit.

Although no fishery importance is accorded to the crocodile shark, some of their life history characteristics like small litter size of four pups per litter (Fujita, 1981; White, 2007) and a tendency for in-utero oophagy (Fujita, 1981; Compagno, 2001) give reason for concern in the light of increasing reports of crocodile shark landing as by-catch of pelagic longline fishery in the south-western Indian Ocean, off Australia (Ariz et al., 2006; Hender et al., 2007). In spite of the distribution range attributed to the species, it has been reported to occur mostly from waters falling within the $20^{\circ} \mathrm{C}$ mean annual sea surface temperature isotherm, and seldom from the higher latitudes in the Indian Ocean (Romanov et al., 2008). The present report thus confirms the occurrence of $P$. kamoharai in warmer waters of the Indian subcontinent.

Conservation status: P. kamoharai has been classified as Near threatened (NT) by International Union for Conservation of Nature (IUCN) (Compagno and Musick. 2000)

\section{Acknowledgements}

We are thankful to Dr. G. Syda Rao, Director, CMFRI, Dr. E. Vivekanandan, Scientist-in-charge, Madras Research Centre of CMFRI and Dr. P.U. Zacharia, Head, Demersal Fisheries Division, CMFRI for the encouragement given. We sincerely thank Dr. Douglas J. Long, Chief Curator, Department of Natural Sciences, Oakland Museum of California, for confirming the identification of the specimen.

\section{References}

Ariz, J., A. Delgado de Molina, M.L. Ramos and J.C. Santana. 2006. Check list and catch rate data by hook type and bait for bycatch species caught by Spanish experimental longline cruises in the south-western Indian Ocean during 2005. Paper presented at IOTC Working Party on Bycatch, 31 July and 1 August 2006, Victoria (Seychelles). IOTC-2006-WPBy-04. 10 p.

Compagno, L.J.V. 2001. Sharks of the world. An annotated and illustrated catalogue of shark species known to date. Volume 2. Bullhead, mackerel and carpet sharks Heterodontiformes, Lamniformes and Orectolobiformes). FAO Species Catalogue for Fishery Purposes. Rome (Italy), FAO, 2[1], 269 p.

Compagno, L.J.V. and J.A. Musick. 2000. Pseudocarcharias kamoharai. In: IUCN 2007. IUCN Red List of Threatened Species. www.iucnredlist.org

D'Aubrey, J.D. 1964. A carchariid shark new to South African waters. Invest. Rep. Oceanogr. Res. Inst. Durban, $16 \mathrm{pp}$

Fujita, K. 1981. Oviphagous embryos of the pseudocarchariid shark, Pseudocarcharias kamoharai, from the Central Pacific. Jpn. J. Ichthyol., 28:37-44.

Hender J. P. Ward, E. Knight and R. Darbyshire. 2007. Pilot Scientific Monitoring Program for the Western Tuna and Billfish Fishery. Final Report (2003-06). BRS, Canberra, Australia. 42 p.

Long, D.J. and J.A. Seigel. 1997. A crocodile shark, Pseudocarcharias kamoharai, (Selachii: Lamnidae) from pelagic waters off Baja California, Mexico. Oceanides 12: $60-63$.

Matsubara, K. 1936. A new carcharoid shark found in Japan. Zoological Magazine (Tokyo) 48(7): 380-382.

Romanov, E.V., P. Ward, J.C. Levesque and E. Lawrence. 2008. Preliminary analysis of crocodile shark (Pseudocarcharias kamoharai) distribution and abundance trends in pelagic longline fisheries. Paper presented at IOTC Working Party on Environment and Bycatch (WPEB) Bangkok, Thailand 20-22 October, 2008 (draft). $29 \mathrm{p}$.

White, William T (2007) Biological Observations On Lamnoid Sharks (Lamniformes) Caught By Fisheries in Eastern Indonesia. J. Mar. Biol. Assoc. UK, 3, 781-788. 